\title{
非周期性を含んだマイクロ球周期構造の熱ふく射特性評価
}

\section{Thermal Radiation Properties of Silica Microstructures with Nonperiodicity}

\author{
○学 脇田 健太郎（九工大院） \\ 池町 希（九工大院） 正 宮崎 康次（九工大）
}

\author{
Kentaro WAKITA, Nozomi IKEMACHI*, Koji MIYAZAKI* \\ Department of Biological Function and Engineering, Kyushu Institute of Technology \\ *Department of Mechanical and Control Engineering, Kyushu Institute of Technology
}

Key Words: Colloidal crystals, Thermal radiation, Diffuse reflection

\section{1. 緒言}

近年, 省エネルギーやエネルギー有効利用の観点から, 加 熱炉などの高温場におけるふく射熱損失の低減や TPV 発電 によるふく射エネルギーの電力への変換など, ふく射エネル ギーの取り扱いが注目されている.MEMS 技術の発達に伴い, フォトニック結晶の表面微細周期構造を用いて, 極めて人工 的な物性による熱ふく射特性を制御できるようになった。し かし, MEMS 技術を基盤として作製される微細構造は, 製造 工程が複雑かつ大面積への作製も困難である。そこで我々は

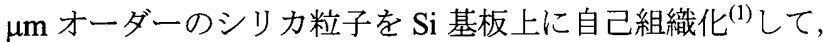
シリカ単体では実現しえない赤外光反射表面を作製した. 構 造表面は, 転位や空孔などの自己組織化による乱れや非周期 性により，やや特徵的なものとなっている，その非周期性が 表面における光の散乱・拡散現象に関係していると考えられ る.

本研究では，マイクロ球自己組織化構造の非周期性と散 乱・拡散現象の関係を解明することを目的とする。 そこで, 厳密結合波解析 ${ }^{(2)}$ (Rigorous Coupled-Wave Analysis :RCWA) を用いて，非周期を持たせた構造の全反射率を計算した。一 方，散乱・拡散現象を実験的に明らかにするために，複回転 放物面鏡法に基づく実験装置を作製し，拡散反射を測定した。 その実験結果と数值計算結果を比較することにより, 微細構 造の非周期性が熱ふく射特性に与える影響を考察した。

\section{RCWA 法を用いた数值計算}

\section{2-1 厳密結合波理論独立散乱の仮定が適用可能とされ} る $c / \lambda>0.5$ ( $c$ は粒子の隙間, $\lambda$ は電磁波の波長）をマイクロ 球自己組織化構造が満たさないため, その散乱現象は従属散 乱となる。つまり，ふく射伝熱輸送方程式に適用できなくな り, 電磁場の計算が必要となる.そこで, 本研究では RCWA 法を用いて従属散乱領域における数值計算を行った.

RCWA 法とは 1980 年代初めに M.G Moharam と T.K. Gaylord が提案した微分法で，マクスウェル・ヘルムホルツ 方程式の境界值問題を解く一つの手法である. 周期構造を深 さ方向にスライスし, 各層における誘電率分布を求める. 各 層における結合波方程式を作り，各層において固有な「モー ド」の線形結合として, 電磁波の一般解を求める. 電磁波に 対する境界条件を与えることにより, 全領域にわたりモード の係数間の比が一意的に決まるため, 全領域の電磁波の状態 がわかる.これにより, 光の強度分布や回折効率, 反射率・ 透過率・吸収率などの計算が可能となる. 本研究では RSOFT 社の電磁波解析ソフトDiffractMODを用いて非周期性をもた せた周期構造の全反射率を数值計算で求めた.
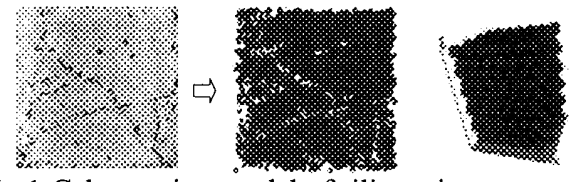

Fig.1 Calucuration model of silica micro-structures

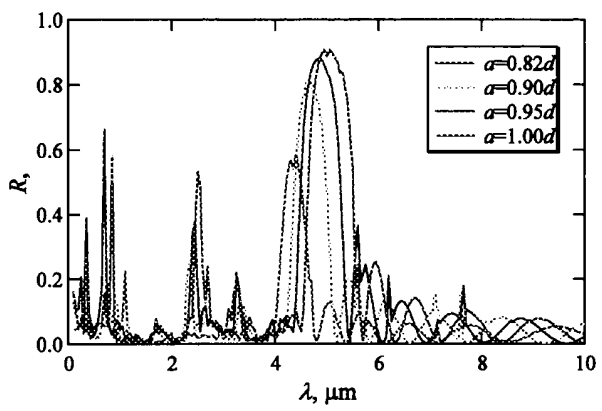

Fig. 2 Total reflection spectra of $2 \mu \mathrm{m}-10$ layered model calculated by RCWA

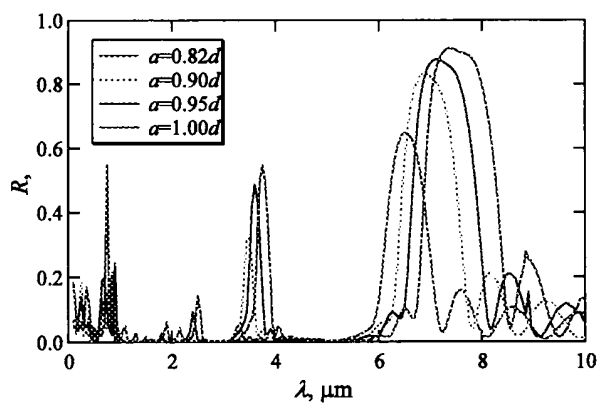

Fig. 3 Total reflection spectra of $3 \mu \mathrm{m}-10$ layered model calculated by RCWA

2-2 数值計算モデル＼cjkstart計算に用いたモデルは, 実際のサン プル表面の顕微画像から画像処理により粒子の配列を読み 込み（図 1 左)，作成した。読み込んだ粒子の層を基準に，3 つの隣接する粒子の重心上に上層の粒子がくるように粒子 を配列した。ただし，各層の粒子の中心は同じ平面上に置い た. 基準の層を $\mathrm{A}$, 次の層を $\mathrm{B}$ とすると $\mathrm{ABAB} \cdots$ となるよう に計 10 積み, 10 層のモデルを作成した（図 1 右). 層の平面 方向は周期境界条件をとっている. 各層間の距離 $a$ は 1 つの モデルで一定とした. 粒子直径を $d$ とした時に, 密な配列で ある $a=\sqrt{6} / 3 d$ から, $a=0.90 d, 0.95 d, 1.00 d$ まで離し, 直径 2 $\mu \mathrm{m}$ と $3 \mu \mathrm{m}$ の 2 種類, 計 8 個のモデルを作成した. 


\section{2-3 計算結果と考察}

図 2 に $2 \mu \mathrm{m}$ 粒子, 図 3 に $3 \mu \mathrm{m}$ 粒 子の計算結果を示す.どちらの結果においても粒子直径の約 2 倍の波長付近においてブラッグ反射による反射の上昇が確 認できた. 一方，粒子直径以下程度の波長領域においても反 射率の上昇がみられる. 各層間の距離が最密である場合と比 較したとき，このような反射率の上昇は完全な周期構造モデ ルの計算結果ではみられない( ${ }^{(3)}$ 。つまり，これは構造の非周 期構造の拡散反射による反射の上昇だと考えられる。また， よ゙ちらのグラフにおいても各層間の距離が離れるに従って 反射率の上昇が強まっている。これは，層間の隙間における 光の散乱の影響が原因だと考えられる。

\section{3. 周期構造作成}

積層法を用いてマイクロ球自己組織化構造を作製した。溶 剤に単分散させたシリカ微粒子（触媒化成工業）を用い，気 液界面での自己組織化現象を利用してシリカの単層膜を生 成, 基板上に一層ずつ積層させる手法により周期構造を作製 した ${ }^{(4)}$. 基板にシリコンウエハ（厚さ $1 \mathrm{~mm}$ ）を使用し，粒 子直径が $2 \mu \mathrm{m}, 3 \mu \mathrm{m}$ のシリカ微粒子をそれぞれ 10 層積層し, 2 種類のサンプルを用意した。

\section{4. 拡散反射測定}

\section{4-1 実験装置拡散反射測定装置の概略図を図 4 に示寸} この光学系は，凹面鏡の焦点に設置された放射源，向かい合 わせになった 2 つ回転放物面鏡，凹面鏡・平面鏡から成っ ている. 放射源は直径 $2 \mathrm{~mm}$ のアルミナ絶縁管に直径 $0.1 \mathrm{~mm}$ のニクロム線を $5 \mathrm{~mm}$ ほど巻いたものを用いた．放射光はま ず凹面鏡・平面鏡により平行化，集光され，中心軸上に穴の 開いた回転放物面鏡内に入射される．その入射光は，入射側 の回転放物面鏡の焦点に設置されたサンプル（中心軸に対し て $20^{\circ}$ 傾いて設置されている）に入射し，拡散反射される. 昖散反射された光は放物面鏡によって平行化され，もう一方 の回転放物面鏡の焦点に集光する. その焦点と自身の焦点が 一致するように凹面鏡を設置し，再び平行化され，他方の開 口に出た反射光を外部光源用の FT-IR（FT/IR-670 plus，日本 分光）を用いて測定した.

4-2 測定方法まず, バックグラウンド測定としてサンプ ルの代わりにアルミミラーを設置し，垂直反射を測定した。 これを参照スペクトル $I_{\mathrm{Al}}(\lambda)$ とする. 次にサンプルに取り替 え，拡散反射スペクトルを測定した。この拡散反射スペクト ルを $I_{\mathrm{r}}(\lambda)$ で表すと, 昖散反射率 $R(\lambda)$ は $R(\lambda)=I_{\mathrm{r}}(\lambda) / I_{\mathrm{Al}}(\lambda)$ で 表される.ただし, 拡散反射測定では非常に微弱な赤外光の 測定を行うため，外乱を受けやすい，特に波長 $3 \mu \mathrm{m}$ 以下で ノイズの影響が顕著である. そのため今回の測定では測定值 の 20 点平均の值をとり, 定量的な值とはなっていない. 本 研究で FT-IRにより測定できた波長領域は 1.5-5 $\mu \mathrm{m}$ である.

4-3 測定結果と考察測定結果を図 5, 図 6 に示寸. 図 5 が $2 \mu \mathrm{m}$ 粒子, 図 6 が $3 \mu \mathrm{m}$ 粒子，それぞれ 10 層積層したサ ンプルの拡散反射スペクトルを示している. 図 6 において約 波長 $4.5 \mu \mathrm{m}$ 付近において反射の上昇が確認できた。これは 図 7 では見られないため, ブラッグ反射によるものであるこ とがわかる. どちらの結果においても, 粒子直径以下の波長 で反射率が上昇していることがわかる。これは，計算結果か らもわかるように，非周期構造の拡散反射によるものである.

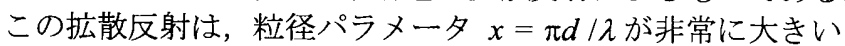
場合のミ一散乱による散乱であると考えられる。ささらに，計 算結果と比較すると, 図 5 から抎散反射による反射がブラッ ク反射と同じ程度上昇していることから, 本研究の積層法で

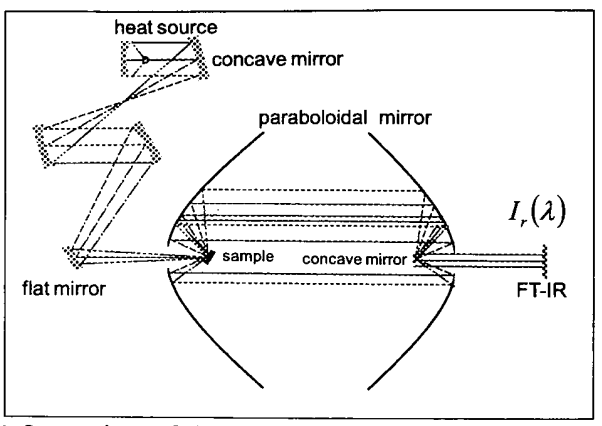

Fig.4 Operation of the measurement of diffuse reflection

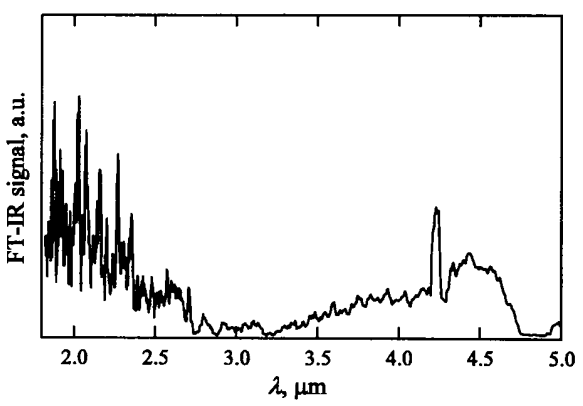

Fig. 5 Diffuse reflection spectra of $2 \mu \mathrm{m}$ - 10 layered sample

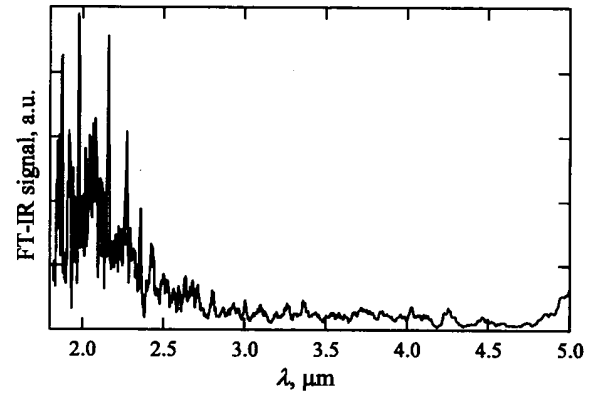

Fig.6 Diffuse reflection spectra of $3 \mu \mathrm{m}-10$ layered sample

作製されたマイクロ球周期構造の各層の粒子は，下の層の粒 子の隙間に密にはまり込んでいるのではなく，ある程度隙間 をもって配列していると考えられる。

\section{5. 結言}

本研究では拡散反射を測定するための装置を開発し，マイ ク口球周期構造の拡散反射率を測定, および, RCWA 法によ る全反射率の計算を行った，両結果より，粒子直径以下の波 長領域において搥散反射が確認された。

\section{謝辞}

本研究は文部科学省科学研究費補助金（基礎研究（A）一般 20246039）（研究代表者 : 牧野俊郎教授 (京都大学)）の援助 を受けた。記して謝意を表する.

\section{参考文献}

(1) Denkov, N. D., Velev, O. D., et al., "Two-dimensional crystallization", Nature, Vol.361, (1993) 26

(2) M.G..Moharam and T. K. Gaylord, "Diffraction analysis of dielectric surface-relief gratings", J.Opt Soc. Am., Vol.72, No. 10/October (1982)

(3) 脇田健太郎，第 46 回日本伝熱シンポジウム講演論文集 Vol. I (2009), 215-216

(4) M.Kihara et al. J. Therm. Sci. Tech. 1 (2006) 12 